\title{
Harmful Memories-Present Dynamics: The Heroic Helper's Effect on Collective and Individual Responsibility and Prejudice
}

\author{
Sára Bigazzi, Fanni Csernus, Sára Serdült, Bálint Takács, Ildikó Bokrétás, Dorottya Géczy \\ Department of Social and Organizational Psychology, University of Pécs, Pécs, Hungary \\ Email: csernus.f@gmail.com
}

How to cite this paper: Bigazzi, S., Csernus, F., Serdült, S., Takács, B., Bokrétás, I. and Géczy, D. (2019) Harmful Memories-Present Dynamics: The Heroic Helper's Effect on Collective and Individual Responsibility and Prejudice. Open Journal of Social Sciences, 7, 176-206.

https://doi.org/10.4236/jss.2019.79014

Received: July 26, 2019

Accepted: September 21, 2019

Published: September 24, 2019

Copyright $\odot 2019$ by author(s) and Scientific Research Publishing Inc. This work is licensed under the Creative Commons Attribution International License (CC BY 4.0).

http://creativecommons.org/licenses/by/4.0/

(c) (i) Open Access

\begin{abstract}
This study was aimed at testing if exposure to a narrative about a heroic helper, can increment responsibility-taking about past ingroup wrongdoings and reduce prejudice and intergroup hostility in the present. We used the narrative of a Hungarian hero in an experiment who acted for targets of the Holocaust in Hungary, and measured if this narrative might increase collective responsibility for the Holocaust, decrease Hungarians' hostile attitudes towards the Jewish minority, and this effect could be expanded to ongoing conflicts with other minorities. We used an experimental group $(\mathrm{N}=99)$ exposed to the narrative, and a control group $(\mathrm{N}=101)$ that was not. Both groups completed a test-battery measuring national identification, empathy, responsibility-taking, and prejudice. Data were analyzed with SPSS, and open-ended questions were content-analyzed by four independent coders. Results show that learning about a heroic helper increased acceptance of responsibility for the Holocaust and empathic abilities, whereas these effects were not generalized to current intergroup relations.
\end{abstract}

\section{Keywords}

Heroic Helper, Empathy, Intergroup Conflict, Prejudice, Responsibility

\section{Heroes in the Present Arising from the Past}

Representations of past intergroup relations and present dynamics mutually influence each other. When memories of harmful past conflicts weigh on the present, recognizing how ingroup members acted against past ingroup norms may facilitate collective elaboration and induce material and symbolic reparation processes. Changing the prevailing value system enables the group to re-evaluate 
the significance of nonconform past ingroup members and to regard them as heroes in the present. The idea that moral exemplars and heroic figures can influence collective emotions, attitudes and behavior, therefore they serve as mediators in intergroup conflicts, comes from the theory that significant historical representations and narrative patterns mediate the outcomes of current social and political affairs [1] [2].

While moral exemplars can be personal (e.g. parents), the hero concerns the whole community. As Lois (2003) notes: "[...] heroes are those people who gain recognition for prioritizing the group's interests over their own. Thus, they can be considered an extreme example at one end of this continuum [self-interest vs. community interest], as they often sacrifice a great deal personally to benefit others." [3]. Heroes are contrasted with everyday people, since they represent great sacrifice and as such are easily idealized, and their deeds and personality are overstated. This issue is tackled in Flanagan's Principle of Minimal Psychological Realism (PMPR): "Make sure, when constructing a moral theory or projecting a moral ideal that the character, decision processing, and behavior prescribed are possible, or are perceived to be possible, for creatures like us" [4]. This approach is also reflected in Philip Zimbardo's term "everyday hero" and in his Heroic Imagination Project. In Zimbardo's view, heroic action is rooted in the current situation and in the stimulation of heroic imagination. As Zimbardo notes: "We believe that an important factor that may encourage heroic action is the stimulation of heroic imagination-the capacity to imagine facing physically or socially risky situations, to struggle with the hypothetical problems these situations generate, and to consider one's actions and the consequences" [5]. Heroic actions provide alternatives and the possibility of a moral choice.

At the same time heroic representations are not universal figures, but heroes' actions are embedded in historical, societal, and political contexts and framed in the normative systems of these contexts [4]. Individuals acting in these contexts accept, conform, ignore and refuse norms, acting in the social arena according to their (more or less) conscious moral choice. Heroes have a social normative context in which they often act against norms, while those who consider them heroes also have their own social normative embeddedness, where a hero's actions are evaluated as morally positive according to these individuals' value system. Hence actions, choices and roles of heroes become reconstructed by others over time. As Halbwachs (1924) raises the question on how memories could live in the frame of the present "Il semble assez naturel que les adultes, absorbés par leurs préoccupations actuelles, se désintéressent de tout ce qui, dans le passé, ne s'y rattache pas. S'ils déforment leurs souvenirs d'enfance, n'est-ce point, précisément, parce qu'ils les contraignent à entrer dans les cadres du présent?" [6]. Values and norms of these others embedded in their social context implicitly guide the reconstruction process itself in such a way that heroes become functional as heroes in the frame of the present, from the perspective of the individuals incorporating values, representing potential actions. Heroes can be considered role models or individuals who embody desired or positively valued ac- 
tions and ways of living.

As the history of past intergroup conflicts influences intergroup relations in the present, present day experiences influence what and how is remembered from the past. Heroes as products of this interplay between the past and the present represent morality change and gaps between normative frames.

In this way the reduction of nowadays intergroup hostility depends on how remembered and elaborated is the past, what we learn about past wrongdoings and victimhoods, are we able to reconciliate, and further to collaborate. Emotional needs arise, however these needs are based on the accepted, often dominant interpretations of the past. We assumed that acknowledging alternative narratives of heroic individuals, disrupting the sense of collective and sharping individual decision-making and responsibility can help to reframe the past, change the way of elaboration and the arousen emotional needs as well. These narratives could affect both victims and perpetrators while the quality of their identification with the group could play a role on it.

\section{Reframing Past Conflicts by Alternative Narratives}

In recent years, research on intergroup conflict and reconciliation focused on the emotional needs of victims and perpetrators [7] [8]. In consistence with the idea that the past weighs on the present [1], the basic tenet of this approach is that harms suffered in past intergroup conflicts may pose continuous identity threat to adversarial groups, which perpetuates mutual distrust and hostility [9] [10], which in turn prevents intergroup contact and reconciliatory efforts. Several alternatives have been proposed how to reduce long-term adversaries' mutual hostility and distrust, which mainly focus on structural interventions fostering trust based on cooperative actions (e.g. trade) and on various forms of public and political gestures to satisfy emotional needs [11]. These interventions mostly concern large-scale international involvement and/or political actions [12].

Another way to promote reconciliation by psychological interventions at a more personal level is presenting ingroup members with alternative, unconventional narratives that reconstruct the historical roles of the adversarial groups in the conflict and also acknowledge alternative perspectives [13] [14] [15]. As Bar-tal notes, "The psychological aspect of reconciliation requires a change in the conflictive ethos, especially with respect to societal beliefs about group goals, about the adversarial group, about the ingroup, about intergroup relations, and about the nature of peace" [16]. However, leaders and the majority of a society often approve and propagate dominant narrative social representations of the past [17] that justify and support ongoing conflicts [18] [19]. The construction and propagation of alternative narratives may enable groups to reframe past and present adversities posed by intergroup conflicts. One of these alternative ways of reconstruction is to show personal roles and stories about distinguished individuals who acted in different ways, which could undermine "the entitative perception of groups" [20]. Bilewicz \& Jaworska (2013) demonstrated that a heroic 
helper's narrative facilitated positive evaluation and perceived similarity of outgroups. However, from the perspective of the needs-based model, only Polish participants felt more accepted, whereas the narrative did not elicit feelings of empowerment in Israeli Jews. The heroic helper evoked in Polish participants the feeling of being more accepted by Jews, which in turn predicted more positive attitudes towards them, which predicted higher perceived similarity of Jews. The Polish hero's positive actions altered the perceived bystander role, which formed the basis of Poles' collective self-image in relation to Jews. With the idea of being more accepted, Jews become more positively evaluated, and more similar [20].

\subsection{Increasing Intergroup Trust by Narratives about Outgroup Heroic Helpers}

It has been proposed that narratives about heroic helpers that disrupt the conventional perception of intergroup conflicts based on the victim and perpetrator roles may contribute to reframing the conflict situation and fostering reconciliation [7] [10] [20] [21] [22] [23] [24].

In two studies, Čehajić-Clancy and Bilewicz (2017) focused on the potential role of moral exemplars in the reduction of intergroup hostility in the post-conflict context in Bosnia and Herzegovina. Conflict-related heterogeneous focus groups worked together with different tools on moral heroes from each side of the conflict to deconstruct the perception of homogeneous past group behaviour. The interventions were based on present intergroup contact and interaction, and they focused on narratives about heroes saving the lives of their adversaries. Interventions increased contact intentions and forgiveness, which mediated belief in reconciliation. Interventions also decreased intergroup anxiety and increased belief in humanity, but these two dimensions had no effect on the belief in reconciliation. As the authors summarize their findings: "narratives including outgroup moral behaviour can help to restore broken relationships by creating a common space in which reconciliation can occur" [21]. These studies tried to increase participants' willingness to reconcile by reframing intergroup conflicts in an intergroup situation with reminders of moral actions of outgroup members, harmonizing the ingroup's and outgroup's positions.

These studies focused on the importance of outgroup heroic helpers in influencing victimized groups' aversive emotions towards a perpetrator group. Moral exemplars increased trust towards the outgroup, which in turn facilitated the willingness to interact [25] [26]. Cross-cultural research also found trust to be one of the closest correlates of forgiveness and reconciliatory intentions [22], although, these psychological processes primarily pertain to victims. It should be noted, however, that moral exemplars or heroic helpers disrupting conventional narratives and roles assigned to the groups, thus enabling different interpretations of the intergroup conflict, have the potential to blur roles according to the dominant positions and assumed moral superiority [27] [28] [29]. Presenting 
the perpetrator's group through individual stories could serve as an alibi and decrease collective guilt of the group, thus inhibiting reparatory intentions [20].

\subsection{Increasing Perpetrators' Moral Responsibility by Narratives about Ingroup Heroic Helpers}

According to Vollhardt \& Bilewitz (2013), "National identities are built around symbolic commemorations of the past and the narratives of victims as well as of perpetrators. Motivated denial of these memories sometimes serves to restore moral self-image among national groups that were once involved in a genocide as bystanders or perpetrators" [24]. According to the needs-based model of reconciliation [7], victims need empowerment as social actors, while perpetrators experience a need for acceptance by others to restore their moral image. However, perpetrator or bystander groups could not establish commemoration of their past wrongdoings, or they could justify them or avoid remembering them, if the normative societal (present institutional ingroup, intergroup or international) frame did not explicitly condemn the actions and events. How people deal with past negative events committed by their group is framed and reframed continuously in the present normative societal frame according to their own continuously changing present identification with the group itself.

When a perpetrator group has a need for restoring their moral image, narratives are usually used as exonerating cognitions [30]. These narratives place them in a passive role, thereby reducing their importance in the aggression. The role of bystanders also needs to be considered. As Staub points out, passivity may be bystanders' response to collective guilt. "Passivity in the face of others' suffering makes it difficult to remain in internal opposition to the perpetrators and to feel empathy for the victims" [31]. Assuming passivity and keeping distance from what is happening allow groups to perceive themselves as victims rather than as bystanders, and this role indirectly contributes to the aggression. In the above mentioned study of Bilewicz \& Jaworska (2013), learning about the heroic helper's actions enabled Polish participants to cope with the weight of passivity presumably assigned to them as bystanders, which helped them feel Jews as more similar and closer to them, diminishing psychological distance [20].

This bystander position maintained over time also prevents coping with the collaboration in collective aggression and feeling guilt, which would be needed for healing, for accepting collective responsibility, and for understanding the importance of acting against unjust or misused authority instead of turning away. In our study, we investigated the impact of a heroic narrative about a member of the perpetrator/bystander ingroup on taking responsibility for the wrongdoings of the ingroup. We expected that the moral exemplar acting against the dominant norms could have different effects depending on national identity. People strongly identifying with the nation, may feel disturbed by an alternative norm, which may lead them to shift responsibility in order to protect 
positive group identity. By contrast, a norm-breaking example could have the opposite effect on non-nationalist people. A sense of responsibility is more likely to be elicited by the story of the moral exemplar offering different alternatives, which may relieve tension and shame by showing alternative patterns of action.

Peetz, Gunn, and Wilson (2010) [32] reported similar findings. German participants decreased temporal distancing of the Holocaust as a self-defensive strategy after being presented with a German heroic helper's example.

Perpetual hostile intergroup relations stem from the collective identification with shared historical narratives about past harms. These narratives serve an important role in maintaining a positive social identity. Thus, most national heroes reinforce the conventional interpretations and possible roles in the conflict situation. Otherwise heroic helpers are often less known historical figures who "blur" the lines between victim and perpetrator by bringing them closer to each other through empathic action. When we consider moral exemplars in an intergroup conflict, these heroic figures often act against the status quo [33].

What is the importance of the status quo or existing normative context? In our study, the heroic helper is a person acting against past group norms by helping victimized outgroup members in a situation where most of the ingroup members are passive or hostile against the minority outgroup. Norms as well as institutionalized laws are essential implicit elements of everyday life, regulating interactions, coexistence and everyday relations. Authority figures may also serve groups and communities with their knowledge and specific competences. However, authority may often be misused, as norms distorted, and such distortions in everyday life gradually rather than abruptly may prevent members of groups and communities from becoming aware of the changes and their consequences. Deliberate closure or perceived impermeability of group boundaries [34], biologization of ingroup and outgroup characteristics, perception of external threat, strengthening identification with the group [35], and decreasing the importance of other roles and group memberships may consolidate ingroup conformity and normative influence. Dissenting voices, norm violations, divergent thoughts and behaviours may question the legitimacy of authority and norms and disrupt growing conformity [36] [37]. Experiencing or getting to know about dissent and norm violation, reduces the perceived homogeneity of the ingroup and their members' behaviour and consequently decreases normative conformity. Tajfel pointed out (1981) the parallels between the continuum of perceived interpersonal-intergroup situations and the perceived heterogeneity-homogeneity of group members' behaviour [38]. The more variability is perceived, the more members think to have a choice of how to act, and thus their choice is less framed by the socially expected and more by their own personal attitudes [38] [39] [40].

We hypothesized that exposure to a narrative about an ingroup heroic helper might break the image of unanimity of group members' behaviour in the specific past context and help individuals in the present to cope with past hostility, to re- 
flect on their collective perpetrator role as a group, to accept collective responsibility, and to reduce hostility towards minorities in the present. We predicted that exposure to the moral exemplar narrative deconstructing the perceived homogeneity [20] [21] and normativity of the group would sufficiently decrease the weight of the moral damage of the group image to cope with past wrongdoings. Coping with past wrongdoings means assuming moral responsibility in both the perpetrator and bystander roles [41], and then being motivated to take reparative actions [42] [43] rather than legitimizing the harm done. Thus, instead of asking participants about perceived similarity and acceptance as Bilewicz and Jaworska (2013) [20] did according to the needs-based model for perpetrator groups [8], we asked them about past and present moral responsibilities.

\subsection{The Role of Identification on the Exposure to Heroic Narratives}

We predicted-in line with the literature on group-based guilt and responsibility-taking-that the ingroup heroic helper's actions would be interpreted in different ways by perpetrator ingroup members with different levels of national identification. Focusing on the paradox of group-based guilt, Roccas, Klar and Liviatan (2006) investigated the factors influencing group members' responses to information interfering with the perceived morality of their group's actions in an ongoing intergroup conflict. The authors resolved the paradoxical connection between group identification and group-based guilt by distinguishing between attachment and glorification as two different modes of identification with the nation. As the authors conclude, these "different modes of identification have opposing relations to feelings of group-based guilt" [30]. While attachment to the nation is part of the self-concept as members of a nation, glorification regards the need to assign moral superiority and distinctiveness to the national ingroup as opposed to other nations, thus strengthening the imagined community. As the national identification can be considered as a "multifaceted construct" [30], and although these different facets are correlated, they have opposite connections with group-related phenomena such as using exonerating cognitions including denial of responsibility and blaming the out-group to avoid negative group-based emotions [44] [45] [46].

Following Tajfel's Social Identity Theory (1979) [47], it can be assumed that identification with groups serves the achievement of a positive and distinctive identity. It is not surprising that strong nationalism, or national glorification, correlates with increased distancing of outgroups, and thus it is connected to a propensity for prejudice. Regarding collective emotions, this form of social identification functions as a defense mechanism, not allowing for critical thinking or negative emotions in relation to one's national ingroup. When group members or leaders act against prevailing national values, they immediately exclude themselves from the national group; there is no room for dissent or critique in the eyes of the glorifier. Exonerating reasoning and denial of responsibility for 
collective wrong-doings are also closely associated with this dimension [48] [49].

Since the belief in national superiority hinders reconciliation processes by increasing prejudicial attitudes [49], we expected that the heroic helper story would increase high glorifiers' (i.e. competitive nationalists') exonerating responses such as denying responsibility and would strengthen the perceived distance from out-groups. By contrast, we predicted that the moral exemplar narrative would have a different effect on participants highly attached to the national ingroup, since attachment is not associated with the need for superiority, therefore it does not inhibit critical assessment of the ingroup's past actions [46]. Both of these effects can be attributed to a heightened sense of collective shame or guilt [50], but these aversive emotions have different effects on glorifiers and attached individuals. The two groups give different focus and weights to group membership, and their emotional responses to past wrongdoings may be different accordingly. Although shame and guilt may be considered similar emotional responses [51], glorification of the nation as a sense of global inferiority accompanied by a need for reinforcement, is more closely associated with shame, which is elicited by facing failures and negatively evaluated ingroup behaviours questioning glorifiers' group identity as a whole and thus motivating avoidance strategies. By contrast, attachment is more likely to be associated with guilt, since highly attached individuals question the morality of specific actions of their group rather than the value of their group identity, and thus they are more open to constructive reparation [52]. Accordingly, Roccas et al. (2006) found that glorification and attachment to Israel among Jewish Israelis were inversely associated with collective guilt for the harm done to Palestinians, and exonerating strategies were only used by high glorifiers [30].

Following the work of Roccas et al. $(2006,2008)$, our study focuses on how the present weighs on the past, and how present perception of, and identification with, the ingroup influence the effects of a moral exemplar narrative [30] [53]. However to make these considerations it is also important to take account of both the past normative context in which the hero acted and the present normative context in which the actor may or may not be considered a hero.

\section{The Historical Contexts of the Study}

Between 1941 and 1945 near 600,000 Hungarian Jews lost their lives during the Holocaust where anti-Jewish laws and decrees (1920, 1938, 1939, 1941, 1942) were deeply rooted in the antisemitic traditions and in the authoritarian ideology of the Horthy regime, an organic expression of the Hungarian political elite's own social agenda. This is well illustrated by the first Numerus Clausus Act introduced in 1920, many years before the National Socialist Party rised to power in Germany. A law enacted in 1941 imposed forced labour service on Jews, as a result of which 100,000 labour servicemen were sent to the front without training, guns, food, and 25,000 to 40,000 of them died before the German occupation of Hungary. Quickly after Hungary allied to Nazi Germany joined WWII in 
1941, nearly 20,000 Jews were deported to German-occupied Ukraine and mass murdered in the city of Kamianets-Podilskyi, while another 1000 Jews were murdered by the Hungarian army in Novi Sad. Hungarian military officials also proposed the deportation of further 100,000 Jews in 1942, but German officials refused Hungarian deportation before 1943 for logistical reasons.

In 1943, however, the situation changed. On one hand, Germany pressured to the ghettoization and deportation of Jews; on the other hand, Hungarian authorities hidden behind a harsh anti-Jewish propaganda and laws tried to avoid deportations, since Horthy began negotiating a separate peace treaty with the Western Allies. However, when Eichmann and twenty other officers arrived in German-occupied Hungary in 1944, they did not have to face any resistance, and with the active collaboration of Hungarian authorities, they deported 437,402 Hungarian Jews in 147 trains in just 56 days between May 15 and July 9, 1944. Horthy legitimized the German occupation until July, when he stopped deportations, then he was toppled from power by Szálasi in October, who sent further 50,000 to 60,000 Jews to death camps ${ }^{1}$.

Nowadays, Hungarian authorities are shifting from acknowledging the complicity of Hungary in the Holocaust to portraying the country as a victim of Nazi occupation. It has to be noted that Prime Minister Orbán declared in July 2017 during Israeli Prime Minister Netanyahu's visit that Hungary chose collaboration instead of protecting Jews during the Holocaust, and that it would never happen again. However, his statement was preceded in the months by an anti-refugee campaign ${ }^{2}$, another campaign against the Hungarian-born Jewish billionaire George Soros ${ }^{3}$, laudation of Horthy, Regent of Hungary during WWII, as an exceptional statesman ${ }^{4}$, celebration of Hungarian politicians and writers with an anti-Semitic past ${ }^{5}$, and efforts for the institutionalization of Hungary's victim status in the Holocaust ${ }^{6}$. A striking example is the monument erected by the government in Liberty Square, Budapest, for the commemoration of the 70th anniversary of the German occupation [54] [55] [56]. The statue depicts Nazi Germany as an eagle, which is attacking archangel Gabriel symbolizing victimized Hungary. Several criticisms pointed out that the statue whitewashed the role that Hungary and its population had in the crimes of the Holocaust.

\section{Past Conflicts and Current Intergroup Relations}

Hirschberger, Kende and Weinstein (2016) studied perceptions of the Hunga-

${ }^{1}$ Data source: website of the United States Holocaust Memorial Museum: https://www.ushmm.org/research/scholarly-presentations/conferences/the-holocaust-in-hungary-70 -years-later/the-holocaust-in-hungary-frequently-asked-questions (last visited on 28.10.2018).

${ }^{2}$ https://www.hrw.org/news/2016/09/13/hungarys-xenophobic-anti-migrant-campaign ${ }^{3}$ https://www.hrw.org/news/2017/09/29/hungary-begins-new-official-hate-campaign ${ }^{4}$ http://hungarianspectrum.org/2017/06/21/in-orbans-opinion-miklos-horthy-was-an-exceptional-st atesman/

${ }^{5}$ http://hungarianfreepress.com/2015/02/03/writings-of-albert-wass-are-a-poor-choice-for-new-york -city-celebration/ [57]

${ }^{6}$ www.mtafki.hu/konyvtar/kiadv/HunGeoBull2016/HunGeoBull_65_3_3.pdf [58] 
rians' role in the Holocaust and found a particularly high correlation between defensive representations of the Holocaust and antisemitism among nationalists [59]. The term defensive representation refers to a "need to modify the group's narrative with regards to its culpability in past atrocities committed against another group" [59]. By defensive representations, the group reduced its own responsibility: they emphasized their victim status or stressed that the group acted under constraint. It is called secondary antisemitism the phenomena when Holocaust perpetrators in their narratives blame the victim to avoid responsibility and guilt [60] [61]. In an experimental study, Imhoff and Banse (2009) found that descendents of perpetrator groups facing outgroup suffering caused by the ingroup experienced increased negative feelings and prejudice towards the victim group [61]. In contrast with our perspective, the authors conclude as follows: "Although it may appear logical to emphasize victim suffering, our findings caution against such an approach. The data suggest that it may be counterproductive in many settings to emphasize victim suffering in an effort to evoke sympathetic reactions and reduce prejudice." [61]. There is a huge difference whether intergroup contact is promoted before or after a perpetrator group faces its past actions and responsibilities. Recognition of, and insight into, past roles and wrongdoings may facilitate identity elaboration and eventually to reframe general intergroup relations. As Cehajic \& Brown (2010) express “acknowledgment of responsibility by collectives entails a notion of 'never again'-the hope that exposure of the past should prevent its future repetition. Through acknowledgment of collective responsibility and provision of punishment, the occurrence of future atrocities can be discouraged" [62].

There are different approaches to the generalization of prejudice across different target-groups. Some of these approaches explain prejudice generalization by personality or individual differences [63] [64] [65] [66], while others refer to the changing normative and ideological context [35] [38] [67] [68] [69]. In consistence with this latter approach, we hypothesize that individuals work with a more generalized image or representation concerning intergroup relations that could be normatively framed. Representations of asymmetric relations have historical triggers and, they are activated in present everyday life when facing context-dependent relevant others. Prejudice as a process of psychological distancing of the relevant other from the self arises as a defense mechanism in response to perceived identity threat [70]. We expected that the story of a past ingroup heroic helper acting against the normative frame of the Holocaust would influence the representations of current intergroup relationships. However, the story in itself does not represent a normative context compelling readers to condemn past events or current conflicts in a changing Hungarian normative system as described below.

Over the past decade, Hungarians' negative attitudes and prejudice towards minorities exponentially grew in part due to threat-based politics and biologization of national membership. Migrants, Gypsies, homosexuals and homeless 
people are all considered others who threaten national identity. We chose in our study the current intergroup relation between Gypsies and the majority involving an ongoing conflict to draw parallels with past conflicts, regarding both Gypsies' not well known victimization during the Holocaust and the present highly consensual prejudice against them [71] [72]. Although blatant prejudice against the Roma minority is common in Hungary (Report of FXB Center for Health and Human Rights, Harvard University, 2014 $)$, hidden forms of prejudice are also wide-spread and institutionalized. None of them may be ignored if the aim is inclusion. Kende et al. (2017) investigated attitudes towards Roma people and found that prejudice against them reflected socially approved dominant norms, which not necessarily involved overt prejudice. The authors point out that discrimination against Roma people may be reduced by reducing the normativeness of anti-Roma bias, which may lead to lower levels of perceived threat and a more inclusive national identity [69].

\section{Research Method}

In this study, we examined the impact of a historical moral exemplar of the ingroup who helped individuals threatened by dominant ingroup norms during a hostile negative event (the Holocaust). We explored the effects of the moral exemplar on the following variables: acceptance of collective responsibility for the past event (PAST-COLLECTIVE) and for hostilities in the present (PRESENT-COLLECTIVE); individual responsibility for ongoing conflicts (PRESENT-INDIVIDUAL); prejudice against major minorities (Jewish, Roma, Muslim and homosexual people); and empathic abilities.

1) In consistence with the literature [30] [48] [73] [74] we hypothesize that identity processes based on group membership (ATTACHMENT-GLORIFICATION) are in general related in different ways to prejudice, acceptance of collective responsibility for past and present conflicts, and empathy. Whilst glorification is related to a more entitative and homogeneous perception of the ingroup and moral superiority over other groups, attachment facilitates cohesion based on group members' common fate without a need for intergroup comparison to maintain positive self-evaluation, and with the possibility to accept ingroup responsibility and the accompanying negative emotions related to the ingroup.

2) We predicted that exposure to the narrative of a heroic helper (STORY) would influence responsibility-taking (PAST-PRESENT), prejudice (towards each group and especially towards Jews) and EMPATHIC abilities (GENERAL EFFECT). These predictions are based on the consideration that learning about a nonconforming heroic helper results in more heterogeneous perception of the ingroup and reduces the weight of collective guilt, thus allowing the group ${ }^{7}$ The report of the FXB Center for Health and Human Rights Harvard School of Public Health and Harvard University: “Accelerating Patterns of Anti-Roma Violence in Hungary” presents evidence from 2008 on increasing violence, murders, paramilitary trainings, and propaganda against Roma people in Hungary. 
members to deal with their group's wrongdoings [32].

3) We predicted that effects of exposure to the heroic helper would be influenced by the identity processes (GLORIFICATION \& ATTACHMENT), since the story would activate a qualitatively different identification that serves as a perspective to interpret and deal with the narrative about the heroic helper.

\subsection{Research Sample}

Participants were recruited via online social media platforms. The total sample $(\mathrm{n}=200)$ consisted of 82 males and 118 females with a mean age of 28.6 years (experimental group $\mathrm{n}=99$; male 42 , female $57, M_{\text {age }}=29$; control group $\mathrm{n}=$ 101; male 42 , female $\left.59, M_{\text {age }}=28\right)^{8}$. The mean value of political orientation on a 7-point scale ranging from left-wing to right-wing was 4.325. Participants' political party preferences were divergent ${ }^{9}$.

No statistically significant differences were found between the experimental and the control group either on the sociodemographic variables or on the input variables of glorification and attachment ${ }^{10}$, that is, differences in the tested variables between the two groups may not be explained by such differences.

\subsection{Procedure}

\subsubsection{Socio-Demographic Data and Identification with the Nation}

Participants completed a complex online questionnaire. First, they provided general demographic questions (gender, age) and indicated their political attitude (on a 7-point scale ranging from left-wing to right-wing and their political party preferences in a multiple-choice response format). Subsequently, they completed the Identification with the Nation scale [48] developed for the Hungarian population by which we assessed Glorification and Attachment as input variables, predicting that they would influence the reception and interpretation of the story read by the experimental group. The Likert-scale consists of 8 items, 4 measuring attachment and 4 measuring glorification. Each item is rated on a 7-point scale according to the extent to which they apply to the respondent.

\subsubsection{Stimulus Narrative about a Heroic Helper}

Hereupon the experimental group read the story about Ocskay (while the control group continued to the next section). The stimulus used in the study was taken from the book Real Heroes by Krisztián Nyáry [75]. The book contains 33 stories about various Hungarian heroic figures including László Ocskay. Nyáry’s

\footnotetext{
${ }^{8}$ The sample size for this research was determined by computing estimated statistical power $(\beta>$ 0.8 ), based on the results of prior experiment about the relation between defensive representations of the Holocaust, nationalism and antisemitism [59].

${ }^{9}$ Other party (33\%), MKKP (“Hungarian Two-Tailed Dog Party”; 20\%), Jobbik (far-right party; $17.5 \%$ ), Fidesz (current ruling party; 16\%), LMP (green party; 6.5\%), MSZP (socialist party; 3.5\%), Együtt-PM (socialist-liberal party; 2\%), DK (democratic coalition; 1\%), Magyar Liberális Párt (liberal party; $0.5 \%)$.

${ }^{10}$ Age: $\mathrm{t}(198)=0.655, \mathrm{p}=0.054$; gender: M2 $(2, \mathrm{~N}=200)=0.014, \mathrm{p}=0.904$; left-right political orientation: $\mathrm{t}(198)=-0.020, \mathrm{p}=0.830$; glorification: $\mathrm{t}(198)=-0.018, \mathrm{p}=0.122$; attachment: $\mathrm{t}(198)=$ $-0.770, \mathrm{p}=0.327$.
} 
book ranked third in the 2014 best seller list of the Hungarian book distributor Líra.

The story was about Captain Ocskay, one of those Hungarians ${ }^{11}$ who hid and saved Jewish individuals when the general public attitude was to active collaboration or to be passive. Captain Ocskay was a WWI veteran of an old aristocratic Hungarian family. In 1944, some Jewish veteran friends asked him to enroll in the army again with the aim to command the labour service unit No. 101/359 in Budapest. At the beginning, they were working in a few hundred but when their number grew to more than two thousand, women, men and children and since they pursued illicit activities they moved to a place less visible to public scrutiny. Ocskay and his staff gave identity cards to new arrivals whenever they escaped from, updated the supposedly official lists, obtained food, medicine and other sustenances for all. He also delegated members of the unit to work with Wallenberg at section $\mathrm{T}$ of the International Red Cross saving children from orphanage at risk of deportation, and he ensured safety for his unit against the intrusion of the Arrow-Cross asking help from German military forces ${ }^{12}$.

\subsubsection{Responsibility at Different Levels}

All participants responded to questions concerning collective responsibility for the Holocaust and individual and collective responsibility for the ongoing conflictual relationship between the majority and the Roma minority. Responsibility was assessed with closed-ended questions and the motivation behind their choices with open-ended questions.

Responses to the open-ended questions were coded by four independent cod$\mathrm{ers}^{13}$. The following variables were examined with open-ended questions:

1) (PAST-COLLECTIVE) Once participants rated (on a 7-point scale) their agreement with the statement "We Hungarians were responsible for the deportation of Jewish people during the Holocaust.", Participants responded indicating the motivation underlying their choice in response to an open-ended question. Responses were sorted under the following codes.

- Subject expressed ${ }^{14}$ : A code focusing on the perspective assumed by participants answers. We used 4 different codes: 1) "we" as the subject (Hungarians); 2) "they", accepting the role of Hungarians, but avoiding responsibility by distancing themselves from their ingroup (e.g. the government at that

${ }^{11} \mathrm{~A}$ list of individuals known to have saved Jewish people during the Holocaust is available at the website of the Holocaust Memorial Center of Budapest:

http://hdke.hu/emlekezes/embermentok/embermentok-nevsora

${ }^{12}$ Source: Research report by Dan Danieli, a surviving member of Ocskay's unit. Available online at the website of the Holocaust Survivors and Remembrance Project: "Forget You Not": http://isurvived.org/Frameset_folder-4DEBATES/4Ocskay/-Ocskay4Debates.html

${ }^{13}$ The research team comprising seven members developed the coding scheme in a bottom-up method using a small sample of responses, constructed a thematic categorisation, and then they trained the four independent coders. The calculation of inter-rater reliability (IRR) was based on the concept of Percent agreement for multiple raters. Inter-rater agreement exceeded the benchmark of $75 \%$ in each case (ranging from $76.5 \%$ to $95.6 \%$ ). All cases of disagreement were discussed by the research team, and final judgments were based on consensus.

${ }^{14}$ Subject expressed $\mathrm{IRR}=89.3 \%$. 
time, the leaders, they/them); 3) did not refer to anyone; 4) denied Hungarians' responsibility.

- Attributed responsibility ${ }^{15}$ : This code measured the attributed responsibility for the Holocaust. We identified 5 categories: 1) the people; 2) the government; 3) not us; 4) Germans; 5) single individuals (this category consisted of those responses that referred to the responsibility of single individuals, but not of others.)

- Internal/External causes ${ }^{16}$ : If the responsibility was explicitly acknowledged, then it was coded as "Responsibility;" if external contextual justifications appeared (e.g. political necessities) it was coded as "Constraint." This distinction is related to our hypothesis that the locus of control has importance in the dynamics of collective victimhood, since constraints and events are viewed to have happened without any kind of control; this indicates a lack of agency and inhibits the psychological elaboration of traumatizing events.

2) (PRESENT-COLLECTIVE) Since we expected that the heroic helper story would indirectly influence current relationships through abstraction and transfer or induce generalization of acknowledgement, participants indicated their agreement on a 7-point scale with the statement that the intergroup relation between the Roma and Non-Roma was one of the most important social issues in current Hungary, then they explained their motivations behind their choice in response to an open-ended question. Responses were coded according to the following scheme:

- Attributed responsibility ${ }^{17}$ : We defined 4 different codes: 1) majority; 2) minority; 3) both; or 4) no attribution.

- Victimhood ${ }^{18}$ : On the basis of the obtained responses, we created 4 different codes concerning the victims of the Roma and Non-Roma conflict: 1) majority; 2) minority; 3) both; or 4) no attributed victimhood.

- Quality of prejudice ${ }^{19}$ : We also identified 4 different types of prejudice and an inclusive perspective in the responses: 1) ethnocentrism; 2) relativism; 3) blaming the victim; 4) colour blindness; and 5) inclusive perspective (no prejudice revealed.)

3) (PRESENT-INDIVIDUAL) Participants used a 7-point scale to indicate their personal responsibility regarding the current intergroup relationship between the Roma and Non-Roma, and they described the motivation behind their choice in response to an open-ended question. Responses were coded according to the following codes:

- Subject expressed ${ }^{20}$ : With this code, we measured participants' acceptance of responsibility for the current conflict. We distinguished between the following subjects in the responses 1 ) personal responsibility indicated by the pro-

\footnotetext{
${ }^{15}$ Attributed responsibility $\mathrm{IRR}=92 \%$

${ }^{16}$ Internal/External causes $\mathrm{IRR}=95.6 \%$

${ }^{17}$ Attributed responsibility IRR $=89.6 \%$.

${ }^{18}$ Victimhood $\mathrm{IRR}=87.4 \%$.

${ }^{19}$ Quality of prejudice IRR $=83.9 \%$.

${ }^{20}$ Subject expressed $\mathrm{IRR}=87.8 \%$.
} 
noun "I"; 2) ingroup responsibility indicated by the pronoun "We"; 3 ) other subject (e.g. government, politicians).

- Responsibility-taking ${ }^{21}$ : We focused on the individuals and investigated participants' acceptance of personal responsibility: 1) accepted personal responsibility; 2) denied personal responsibility; 3) made no reference to personal responsibility.

- Object of responsibility ${ }^{22}$ : With this code, we marked the group for which participants felt responsible as follows: 1) Roma minority; 2) non-Gypsy majority; 3) both groups; or 4) none of them.

\subsubsection{Empathy and Prejudice}

Empathy was measured with the Interpersonal Reactivity Index [76]. According to Davis, empathy can be defined as the "reactions of one individual to the observed experiences of another". The IRI measures 28 intrapersonal processes that mediate responses to others' behaviour in interpersonal relations. The test consists of four subscales: Perspective taking (7 items), Empathic concern (7 items), Fantasy (7 items) and Personal Distress (7 items). Participants indicated on a 5-point scale how accurately each item characterizes them: (e.g. "I can truly feel the emotions of a novel s character.")

Finally, we measured explicit prejudice with the Bogardus social distance scale [77]. Participants used the following items to indicate the closeness of the relationships they would be willing to accept with members of the following groups: Germans, Gypsies, Muslims, Jews, homosexuals: "as a citizen of your country; as a colleague; as your neighbour; as a close friend; as a family member".

\section{Results}

We explored data on the overall sample without taking account of possible effects of the stimulus. Mean attachment to the nation was $19.280(\mathrm{SD}=5.56)$ on a Likert-scale ranging from 4 to 28 ; mean glorification was $14.615(\mathrm{SD}=4.931)$ on a Likert-scale ranging from 4 to 28 . We examined correlations between the tested variables and found that political orientation showed a significant positive correlation with glorification $\left(r(\mathrm{n}=200)=0.373^{\star *}, p<0.001\right)$, attachment $\left(r(\mathrm{n}=200)=0.228^{\star *}, p=0.001\right)$, and with social distance from Gypsies $(r(\mathrm{n}=$ $\left.200)=0.260^{* *}, p<0.001\right)$, Muslims $\left(r(\mathrm{n}=200)=0.251^{\star *}, p<0.001\right)$, homosexuals $\left(r(\mathrm{n}=200)=0.166^{\star}, p=0.019\right)$ and Jews $\left(r(\mathrm{n}=200)=0.222^{* *}, p=0.002, r^{2}\right.$ $=0.050)$. Participants' political orientation was related to national identification processes and to social distance from various context-relevant Others. The more right-oriented one was, the higher attachment to, and glorification of, the Hungarian national ingroup one reported, and the greater psychological distance one kept from relevant outgroups and minorities.

\footnotetext{
${ }^{21}$ Responsibility-taking IRR $=76.5 \%$.

${ }^{22}$ Object of Responsibility IRR $=79.2 \%$.
} 


\subsection{Identification Processes Related Variables: "A Stranger Power Forced Us" (H1)}

We found that while attachment correlated with each of the four subfactors of empathy: Fantasy $\left(r(\mathrm{n}=200)=0.226^{\star *}, p=0.001, r 2=0.050\right)$; Empathic concern $\left(r(\mathrm{n}=200)=0.406^{* *}, p<0.001\right)$; Perspective taking $\left(r(\mathrm{n}=200)=0.245^{\star *}, p\right.$ $<0.001)$; Personal distress $\left(r(\mathrm{n}=200)=0.158^{\star}, p=0.026\right)$. By contrast, glorification did not show significant correlation with any of the empathy factors ${ }^{23}$ (see Table 1).

Glorification positively correlated with most social distance scales: Jews $(r(\mathrm{n}$ $\left.=200)=0.274^{\star *}, p<0.001, r^{2}=0.075\right)$; Muslims $\left(r(\mathrm{n}=200)=0.213^{\star *}, p=\right.$ $0.002)$; Homosexuals $\left(r=(\mathrm{n}=200)=0.342^{* *}, p<0.001\right)$; Gypsies $(r(\mathrm{n}=200)=$ $\left.0.195^{\star *}, p=0.006\right)^{24}$. By contrast, it negatively correlated with ingroup responsibility for the Holocaust $\left(r(\mathrm{n}=200)=-0.365^{* *}, p<0.001\right)$ and with personal responsibility for the conflict with Gypsies $\left(r(\mathrm{n}=200)=-0.211^{\star *}, p=0.003\right)$. Attachment did not correlate with any of these items ${ }^{25}$ (see Table 1 ).

We predicted (H1) that attachment and glorification would show opposite correlations with ingroup responsibility for past conflicts, individual responsibility for the current intergroup conflict, empathy, and prejudice. The results indicate that while both attachment to, and glorification of, the national ingroup were related to political orientation, they activated different processes. While attachment a relationship with empathic abilities, glorification was associated with social distance from others and with acceptance of collective and individual responsibility-taking for intergroup conflicts.

Table 1. Correlation between identification types and empathy, social distance and responsibility taking.

\begin{tabular}{|c|c|c|c|}
\hline & & Attachment & Glorification \\
\hline \multirow{4}{*}{$\begin{array}{l}\text { Interpersonal } \\
\text { reactivity index }\end{array}$} & Fantasy & $r=0.226^{* *}, p=0.001$ & $n s$ \\
\hline & Empathic concern & $r=0.406^{* *}, p<0.001$ & $n s$ \\
\hline & Perspective taking & $r=0.245^{* *}, p<0.001$ & $n s$ \\
\hline & Personal distress & $r=0.158^{*}, p=0.026$ & $n s$ \\
\hline \multirow{4}{*}{ Social distance } & Jews & $n s$ & $r=0.274^{* *}, p<0.001$ \\
\hline & Muslims & $n s$ & $r=0.213^{* *}, p=0.002$ \\
\hline & Homosexuals & $n s$ & $r=0.342^{* *}, p<0.001$ \\
\hline & Gypsies & $n s$ & $r=0.195^{* *}, p=0.006$ \\
\hline \multicolumn{2}{|c|}{ Ingroup responsibility for Holocaust } & $n s$ & $r=-0.365^{* *}, p<0.001$ \\
\hline \multicolumn{2}{|c|}{ Personal responsibility for current conflict } & $n s$ & $r=-0.211^{* *}, p=0.003$ \\
\hline $\begin{array}{l}\text { Fantasy }(\mathrm{r}(\mathrm{n}=200) \\
\text { ctive taking }(r(\mathrm{n}=2 \\
\text { Except social distanc } \\
\text { ngroup responsibilit }\end{array}$ & $\begin{array}{l}16, \mathrm{p}=0.822) ; \mathrm{Em} p \\
.059, p=0.406) ; \mathrm{Pe} \\
\text { the German minori } \\
\text { he Holocaust: }(r(\mathrm{n}= \\
\text { fflict: }(r(\mathrm{n}=200)=\end{array}$ & $\begin{array}{l}\text { ic concern }(\mathrm{r}(\mathrm{n}=200)= \\
\text { nal distress }(r(\mathrm{n}=200)= \\
(r(\mathrm{n}=200)=0.098, p= \\
00)=-0.070, p=0.326)\end{array}$ & $\begin{array}{l}=0.071, \mathrm{p}=0.317) ; \text { Pers- } \\
=-0.127, p=0.072) \\
0.167) \text {. } \\
\text {; Personal responsibility }\end{array}$ \\
\hline
\end{tabular}


These results were confirmed by our content codes of responses to the open-ended questions. From Figure 1 we can see that ANOVA tests revealed a difference in glorification according to the subject of collective responsibility for the Holocaust (code 1. Subject expressed). Higher levels of glorification were reported by those who referred to Hungarians, but accepted no collective responsibility $(M=16.28, S D=5.15)$ or made no reference $(M=16.6, S D=4.5)$ than by those who referred to "Hungarians" as "them" ( $\mathrm{M}=12.0, \mathrm{SD}=4.43$; $\left.F(4195)=4.291, p=0.002, \eta^{2}=0.081\right)$. Those who held the Germans responsible for the Holocaust (code 1. Attributed responsibility showed significantly higher levels of glorification ( $\mathrm{M}=16.73, \mathrm{SD}=4.2)$ than those who attributed responsibility to the Hungarian people $(\mathrm{M}=13.78, \mathrm{SD}=4.89)(F(4194)=2.6, p=0.037$, $\eta^{2}=0.051$ ) (see Figure 1). Those who argued that the Hungarians acted under constraint (code 1. Internal/External causes) had higher levels of glorification (M $=15.9, \mathrm{SD}=4.91)$ than those who accepted Hungarians' responsibility $(\mathrm{M}=$ $13.34, \mathrm{SD}=4.9)\left(F(2197)=4.119, p=0.018, \eta^{2}=0.053\right)($ see Figure 1$)$. No significant difference was found in attachment by content codes ${ }^{26}$. These content-related results corroborate findings reported by Hirschberger et al. (2016): high glorifiers used more defensive representations or exonerating cognitions concerning the Holocaust, depicting it as one of our respondent argued: " $A$ stranger power forced us from the first anti-Jewish laws of the '30 s'" [59].

We also revealed differences in identification according to the responses to the question concerning the acknowledgment of the Gypsy-majority intergroup conflict. Results presented in Figure 2 show significantly higher glorification by those who blamed the minority $(\mathrm{M}=15.66, \mathrm{SD}=4.85)$ or both the minority and majority $(\mathrm{M}=13.94, \mathrm{SD}=4.78)$ (code 2. Attributed responsibility) as compared to those only blaming the majority $(\mathrm{M}=11.5, \mathrm{SD}=4.53 ; F(3196)=4.345, p=$ $0.005, \eta^{2}=0.062$ ). Likewise, significantly higher glorificationwas found for those who held that the majority $(M=15.15, S D=5.48)$ or both groups $(M=15.0, S D$ $=5.02$ ) were the victims of the current conflict (code 2. Victimhood), rather than the Minority as the only victim $(\mathrm{M}=11.52, \mathrm{SD}=4.93) ;(F(3196)=3.551, p=$ $0.015, \eta^{2}=0.052$ ) (see Figure 2). We also found that participants with higher glorification exhibited higher levels of ethnocentric prejudice $(\mathrm{M}=15.04, \mathrm{SD}=$ 5) compared to other types (code 2. Quality of prejudice): colour blindness ( $\mathrm{M}=$ $12.0, \mathrm{SD}=3.31)$, relativism $(\mathrm{M}=11.78, \mathrm{SD}=4.02)$, blaming the victim $(\mathrm{M}=$ $12.69, \mathrm{SD}=5.27)$ or an inclusive perspective $(\mathrm{M}=12.2, \mathrm{SD}=5.33)(F(5194)=$ 2.710, $p=0.022, \eta^{2}=0.065$ ) (see Figure 2). No significant difference was found between response categories in attachment ${ }^{27}$. These results show that glorification and exonerating strategies are connected in ongoing conflicts:, responsibility for the intergroup conflict is attributed to the Minority, while the victim's role is assigned to the ingroup.

\footnotetext{
${ }^{26}$ Subject expressed: $F(4195)=0.997, p=0.410 ;$ Attributed responsibility: $F(4194)=0.327, p=0.859$; Internal/External causes: $F(2197)=0.001, p=0.999$.

${ }^{27}$ Attributed responsibility: $F(3196)=0.099, p=0.961 ;$ Victimhood: $F(3196)=0.094, p=0.963$; Quality of prejudice: $F(5194)=2.169, p=0.059$.
} 


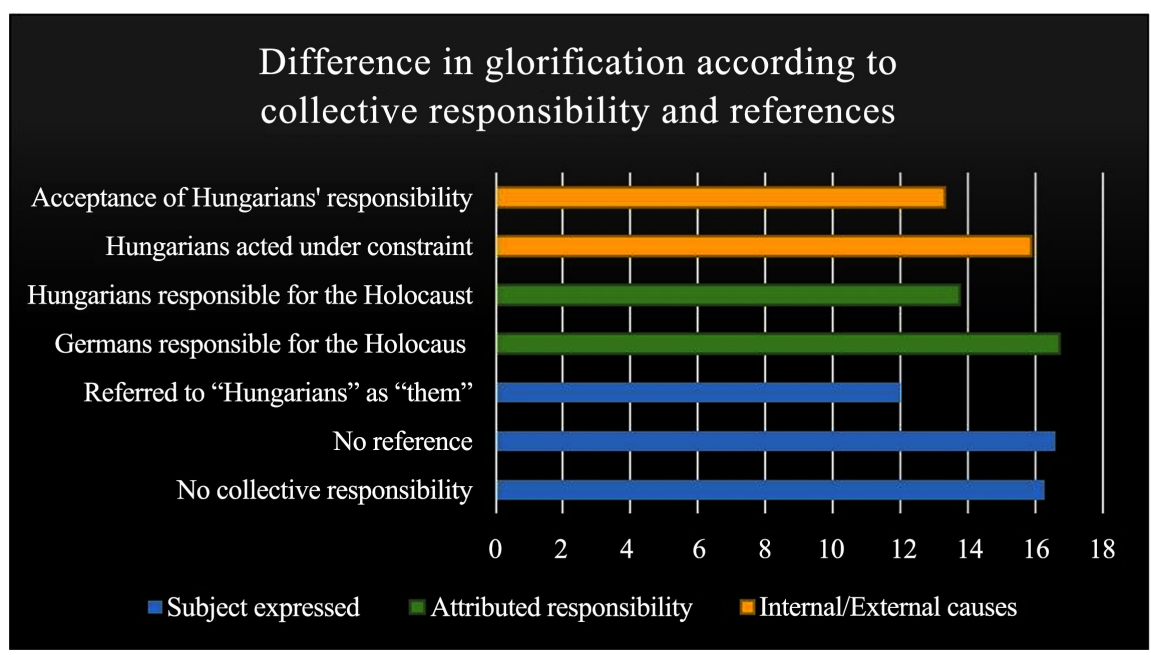

Figure 1. Difference in glorification according to collective responsibility-taking and references.

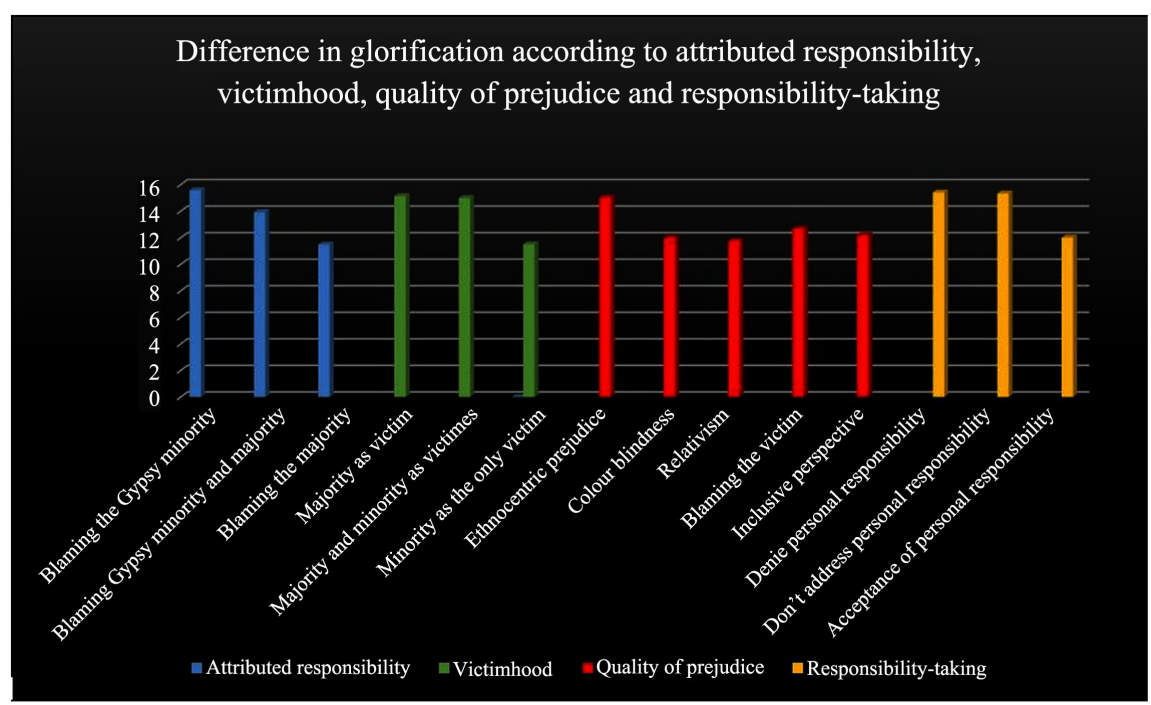

Figure 2. Difference in glorification according to blaming, victimhood, quality of prejudice and responsibility-taking.

Concerning the question related to personal responsibility for the Gypsy-majority conflict (code 3. Responsibility-taking), significantly higher glorification was shown by those who denied $(\mathrm{M}=15.43, \mathrm{SD}=4.8)$ or did not address personal responsibility at all $(\mathrm{M}=15.34, \mathrm{SD}=4.72)$ as compared to those accepted that $(\mathrm{M}=12.02, \mathrm{SD}=4.66)\left(F(3196)=5.501, p=0.001, \eta^{2}=0.078\right)$. No significant difference was found in attachment according to these $\operatorname{codes}^{28}$ (see Figure 2).

Content codes, presented in Table 2 also confirm that glorification of the national ingroup is strictly related to responsibility avoidance, both concerning past ingroup conflicts, current intergroup conflicts and recognition of the individual's own activity and personal responsibility.

${ }^{28}(F(3196)=0.276, p=0.843)$. 
Table 2. Correlation between intergroup relation, responsibility taking, empathy and social distance.

\begin{tabular}{|c|c|c|c|c|}
\hline & & $\begin{array}{c}\text { Hungarians } \\
\text { responsibility for } \\
\text { Holocaust }\end{array}$ & $\begin{array}{c}\text { Gypsy-majority } \\
\text { intergroup conflictual } \\
\text { relation }\end{array}$ & $\begin{array}{l}\text { Personal } \\
\text { responsibility for } \\
\text { current conflict }\end{array}$ \\
\hline \multicolumn{2}{|c|}{ Glorification } & - & $n s$ & - \\
\hline \multicolumn{2}{|c|}{ Attachment } & $n s$ & $n s$ & $n s$ \\
\hline \multirow{6}{*}{$\begin{array}{c}\text { Social } \\
\text { distance }\end{array}$} & Gypsies & - & + & - \\
\hline & Jews & - & + & - \\
\hline & homosexuals & - & $n s$ & - \\
\hline & Muslims & - & $n s$ & - \\
\hline & Germans & - & $n s$ & $n s$ \\
\hline & Fantasy & + & $n s$ & + \\
\hline \multirow{3}{*}{$\begin{array}{l}\text { Interpersonal } \\
\text { reactivity } \\
\text { index }\end{array}$} & $\begin{array}{l}\text { Empathic } \\
\text { concern }\end{array}$ & + & - & + \\
\hline & $\begin{array}{l}\text { Perspective } \\
\text { taking }\end{array}$ & + & $n s$ & + \\
\hline & $\begin{array}{c}\text { Personal } \\
\text { distress }\end{array}$ & + & $n s$ & $n s$ \\
\hline \multicolumn{2}{|c|}{$\begin{array}{l}\text { Ingroup responsibility for } \\
\text { Holocaust }\end{array}$} & & - & + \\
\hline
\end{tabular}

Responsibility attributed to the Hungarians for the Jewish Holocaust correlated negatively with glorification $\left(r(\mathrm{n}=200)=-0.365^{* *}, p<0.001\right)$ and with all social distance scales: Jews $\left(r(\mathrm{n}=200)=-0.309^{* *}, p<0.001\right)$, Gypsies $(r(\mathrm{n}=$ $\left.200)=-0.322^{* *}, p<0.001\right)$, Muslims $\left(r(\mathrm{n}=200)=-0.308^{* *}, p<0.001\right)$, homosexuals $\left.\left(r(\mathrm{n}=200)=-0.343^{* *}, p<0.001\right)\right)$, and with social distance from the German minority $\left(r(\mathrm{n}=200)=-0.220^{* *}, p=0.002\right)$. Responsibility attributed to the Hungarians for the Jewish Holocaust showed a low positive correlation with all empathy factors: Fantasy $\left(r(\mathrm{n}=200)=0.277^{* *}, p<0.001, r 2=0.08\right)$; Empathic concern $\left(r(\mathrm{n}=200)=0.169^{*}, p=0.017\right)$; Perspective taking $(r(\mathrm{n}=200)=$ $\left.0.165^{* *}, p=0.020\right)$; Personal distress $\left(r(\mathrm{n}=200)=0.203^{*}, p=0.004\right)$. The direction of correlations is presented in Table 2.

Perception of the Gypsy-majority intergroup relation as conflictual negatively correlated with empathic concern $\left(r(\mathrm{n}=200)=-0.228^{\star *} p=0.001\right)$, positively correlated with social distance from Gypsies $\left(r(\mathrm{n}=200)=0.293^{* *}, p<\right.$ $0.001)$ and Jews $\left(r(\mathrm{n}=200)=0.162^{\star}, p=0.022\right)$, and showed a low negative correlation with responsibility of Hungarians in the Jewish Holocaust $(r(\mathrm{n}=200)=$ $\left.-0.143^{*}, p=0.043\right)$. Thus, a small tendency emerges in the data which shows that those perceiving current intergroup relations with Gypsies as conflictual attribute less responsibility to their own group concerning past conflicts (see Table 2).

Acceptance of personal responsibility for the ongoing intergroup relation showed a moderate positive correlation with the responsibility attributed to the Hungarians for the Holocaust $\left(r(\mathrm{n}=200)=0.377^{* *}, p<0.001\right)$, low positive correlations with the empathy factors of fantasy $\left(r(\mathrm{n}=200)=0.143^{\star}, p=0.043\right)$, 
empathic concern $\left(r(\mathrm{n}=200)=0.169^{*}, p=0.017\right)$ and perspective taking $(r(\mathrm{n}=$ $\left.200)=0.229^{* *}, p=0.001\right)$, and a low negative correlation with social distance scale of Gypsies $\left(r(\mathrm{n}=200)=-0.227^{\star *}, p=0.001\right)$, Jews $\left(r(\mathrm{n}=200)=-0.222^{\star *}\right.$, $p=0.002)$, Muslims $\left(r(\mathrm{n}=200)=-0.215^{\star *}, p=0.002\right)$, homosexuals $(r(\mathrm{n}=200)$ $\left.=-0.196^{* *}, p=0.005\right)$. In sum, higher personal responsibility is associated with higher perceived ingroup responsibility, better empathic abilities and reduced social distance from others (see Table 2).

Summing up, our first hypothesis was confirmed. While attachment to the nation was in relation only with the empathic abilities, glorification was positively connected to prejudice, negatively to individual and collective responsibility, as those who are using exonerating strategies for past group wrongdoings, blame Minority and feel to be victim in current conflict are significantly higher glorifiers.

\subsection{Effects of the Heroic Story (H2)}

Our second Hypothesis (H2) concerned the direct effect of the heroic helper on perceived ingroup responsibility for the past wrongdoings and for the current intergroup conflict and the acceptance of individual responsibility for the intergroup conflict. We found that the story about the Hungarian heroic helper increased the responsibility attributed to the Hungarians for the Holocaust $\left(\mathrm{M}_{\text {experimental }}=4.414 ; \mathrm{M}_{\text {control }}=3.861 ; \mathrm{t}(198)=2.201, \mathrm{p}=0.029, \mathrm{~d}=0.31\right)$, while this effect was not generalized to perception of the Gypsy-majority intergroup relation as conflictual ${ }^{29}$, to individual responsibility for the intergroup conflict ${ }^{30}$, or to social distance ${ }^{31}$ (see Figure 3 ).

Concerning the content codes, we found differences between the experimental and the control group only in acceptance of personal responsibility. Those who read the story about Ocskay considered their own or their group's responsibility in current intergroup relations, using the personal pronouns " $\mathrm{I}$ " and "We" more frequently than those who were not presented with the story (M2 (n $=200)=9.391 p=0.025, \mathrm{~V}=0.217$ ) (see Figure 3). According to Pennebaker work on pronouns (2011) the increased use of self reference words refers to increased activity.

From Figure 3 we can see that the stimulus narrative was associated with increased levels of three of the four empathy factors measured by the Interpersonal Reactivity Index (with theexception of Personal distress; Fantasy $\mathrm{M}_{\text {experi- }}$ mental $=3.85 ; \mathrm{M}_{\text {control }}=3.5 ; t(198)=3.123, p=0.002, d=0.44 ;$ Perspective taking $\mathrm{M}_{\text {experimental }}=3.62 ; \mathrm{M}_{\text {control }}=3.38 ; t(198)=2.387, p=0.018, d=0.33$; Empathic concern $\mathrm{M}_{\text {experimental }}=3.64 ; \mathrm{M}_{\text {control }}=3.43 ; t(198)=2.070, p=0.040, d=0.29$ ).

${ }^{29} \mathrm{M} 1=4.788 ; \mathrm{M} 2=5.099 ; \mathrm{t}(198)=-1.379, \mathrm{p}=0.169$.

${ }^{30} \mathrm{M} 1=3.253 ; \mathrm{M} 2=3.178 ; \mathrm{t}(198)=0.272, \mathrm{p}=0.786$.

${ }^{31}$ Germans: $\mathrm{M} 1=1.190, \mathrm{M} 2=1.194, t(198)=0.262, p=0.793$; Gypsies: $\mathrm{M} 1=3.465, \mathrm{M} 2=3.564$, $t(198)=-0.413, p=0.680$; Muslims: $\mathrm{M} 1=3.343, \mathrm{M} 2=3.683, t(198)=-1.377, p=0.170$; Jews: $\mathrm{M} 1=$ $2.242, \mathrm{M} 2=2.663, t(198)=-1.078, p=0.282$; homosexuals: $\mathrm{M} 1=2.394, \mathrm{M} 2=2.733, t(198)=$ $-1.453, p=0.148$. 


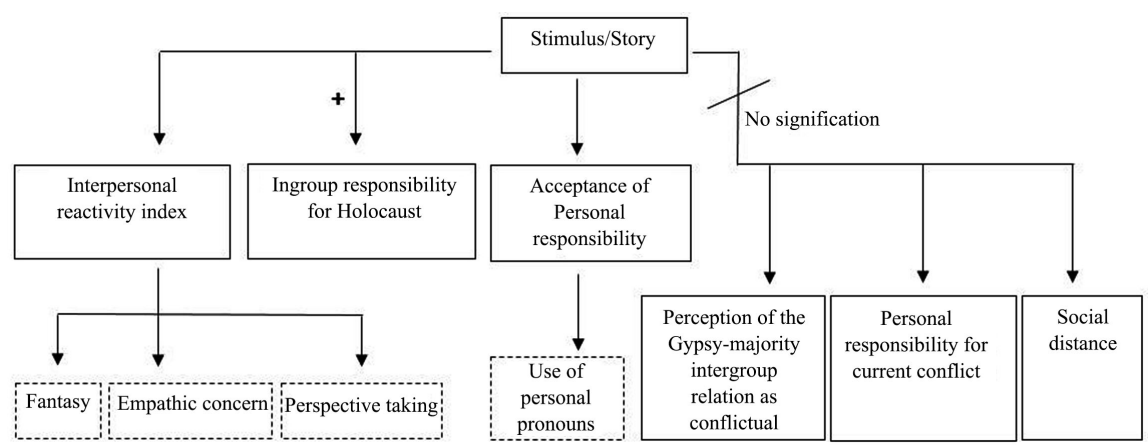

Figure 3. Effects of the heroic story.

The results lead to the conclusion that reading the story of Ocskay had a general effect on participants' views on the Holocaust, in whose context the recounted events took place. Those who read the story attributed essential responsibility to the Hungarians for the Holocaust, used more first-person personal pronouns reflecting their acceptance of personal responsibility and reported better empathic competences in self-reporting empathy.

However, the ingroup helper story did not have more general effects: it did not influence participants' perception of a current conflictual intergroup relation (i.e. the Gypsy-majority conflict), did not clearly facilitate acceptance of personal responsibility, and did not decrease social distance from others. We hypothesized that this restricted effect was due to the mediation effect of glorification of the national ingroup, which acted as a blocking mechanism against the evaluation of current intergroup conflicts and relations.

Summing up, our second hypothesis concerning the effects of the heroic narratives on individuals was partially confirmed. Those who read the story increased ingroup responsibility, however did not generalized to the current situations. The exposure to the heroic helper narrative increased also empathic abilities and in an indirect way personal responsibility as well (increased use of first person personal pronouns).

\subsection{Identification and the Heroic Helper Story (H3)}

To test this hypothesis (H3), we ran the PROCESS macro [78] with glorification as a moderator variable, but no significant moderation effect was found for ingroup responsibility for the Holocaust, acknowledgment of the Gypsy-majority conflict, personal responsibility for this conflict, empathy factors or any of the Bogardus scales (i.e. Gypsies, Muslims, Jews, homosexuals). It seems that identification with the national ingroup did not moderate the effects of the story on dependent variables such as different levels of responsibility-taking, empathy or prejudice.

However, since these variables showed no differences between the experimental and the control group with regard to the mediation effect of the national identification variables, we examined the correlation matrix of the tested variables in the two subsamples, which revealed differences (see Table 3). In the 
experimental condition, glorification primarily varied mainly with those variables that represent intergroup hostility, while no such relationships were found in the control condition (apart from the positive correlation with social distance from homosexuals and the negative correlation with responsibility attributed to Hungarians for the Holocaust). The negative correlation found between glorification and personal responsibility was not significant in the experimental condition as opposed to the control condition.

Results presented in Table 3 show that attachment was less related to the intergroup variables except for the perception of current intergroup hostility which covariated in the experimental condition. Furthermore, although attachment was related to the emotional competences of empathy in both conditions, it showed a lower correlation with empathic concern in the experimental condition. Thus, attachment also acted as a national identity activator not directly influencing intergroup relations but rather empathic concern for others in general.

We interpreted these data as follows. Although the two subsamples had no differences in means and variances of the tested variables, the story of the ingroup helper activated group identification processes. Glorification showed higher correlations with all intergroup variables in the experimental condition. Attachment enabled individuals to identify with the ingroup, but it was less closely related to empathic competences in the experimental situation than in the control condition without the context constructed through the stimulus.

Table 3. Correlations between the tested variables in the experimental and control condition.

\begin{tabular}{|c|c|c|c|}
\hline & & $\begin{array}{l}\text { Experimental group } \\
\qquad(\mathrm{n}=99)\end{array}$ & $\begin{array}{l}\text { Control group } \\
(\mathrm{n}=101)\end{array}$ \\
\hline \multirow{7}{*}{ Glorification } & $\begin{array}{l}\text { Social distance } \\
\text { from Gypsies }\end{array}$ & $r=0.292^{* *}, p=0.003$ & $r=0.094, p=0.349$ \\
\hline & $\begin{array}{l}\text { Social distance } \\
\text { from Jews }\end{array}$ & $r=0.349^{* *}, p<0.001$ & $r=0.188, p=0.060$ \\
\hline & $\begin{array}{l}\text { Social distance from } \\
\text { homosexuals }\end{array}$ & $r=0.344^{* *}, p<0.001$ & $r=0.337^{* *}, p=0.001$ \\
\hline & $\begin{array}{l}\text { Social distance } \\
\text { fromMuslims }\end{array}$ & $r=0.266^{* *}, p=0.008$ & $r=0.149, p=0.138$ \\
\hline & $\begin{array}{l}\text { Ingroup responsibility } \\
\text { for Holocaust }\end{array}$ & $r=-0.415^{* *}, p<0.001$ & $r=-0.300^{* *}, p=0.002$ \\
\hline & $\begin{array}{l}\text { Minority-majority } \\
\text { conflict }\end{array}$ & $r=0.250^{*}, p=0.013$ & $r=-0.065, p=0.521$ \\
\hline & $\begin{array}{l}\text { Personal responsibility } \\
\text { for current conflict }\end{array}$ & $r=-0.184, p=0.069$ & $r=-0.242^{*}, p=0.015$ \\
\hline \multirow{4}{*}{ Attachment } & $\begin{array}{l}\text { Minority-majority } \\
\text { conflict }\end{array}$ & $r=0.239^{*}, p=0.017$ & $r=-0.025, p=0.801$ \\
\hline & Fantasy & $r=0.204^{*}, p=0.043$ & $r=0.251^{*}, p=0.011$ \\
\hline & Perspective taking & $r=0.240^{*}, p=0.017$ & $r=0.256^{* *}, p=0.010$ \\
\hline & Empathic concern & $r=0.268^{* *}, p=0.007$ & $r=0.536^{* *}, p<0.001$ \\
\hline
\end{tabular}


Summing up, our third hypothesis was not corroborated; the type of identification did not mediate the effect of the heroic helper narrative. At the same time there was a small effect, in the experimental condition, after reading the story, thus being contextualized, individuals answered more "coherently" in relation to their activated national identity. Glorification in the experimental condition shows major relation to prejudice, as well as to the avoidance of responsibility for the Holocaust, and more to the perception of current conflicts. The out of context attachment related empathical competences become less related to it.

\section{Discussion}

Similarly to the research and conceptualisation published by Roccas et al. (2006, 2008) [30] [53] and confirming the results of Hirschberger et al. (2016) [59], we found that glorification of the nation was related to generalized prejudice towards different groups, to less willingness to accept responsibility for the ingroup's past wrong-doings and ongoing conflictual relations, and to the use of different exonerating cognitions such as responsibility denial, blaming the outgroup, and moral justification referring to constraint. While attachment was not related to any of these dimensions, glorification as a mode of national identification covaried with different levels of accepted responsibility for past misdeeds of the ingroup and for the present individual role in an ongoing intergroup conflict.

Individual responsibility in current intergroup situations provides the prospect of more peaceful intergroup relations. Taking personal responsibility for intergroup situations may predict individuals' proneness to act according to their individual value systems rather than conforming to group norms or executing orders. In our data, this mental predisposition towards more peaceful intergroup relations was reflected in less prejudice and a better perspective-taking ability associated with individual responsibility for ongoing intergroup conflicts. Furthermore, individual responsibility for the ongoing conflict was closely related to the assumed ingroup responsibility for the Holocaust. Considering the reconstructive nature of memory, the relationship between past and present responsibilities is not a linear one of causes and consequences; living responsibly in the present requires learning from the past, and vice versa-recognizing the importance of dealing with the past requires a sense of responsibility in the present. Individual responsibility and thus participation in the public sphere and engaging in more balanced intergroup relations are strictly related with taking responsibility for past wrongdoings.

We based our analysis on previous studies of the impact of heroic helpers. In these studies, narratives about heroic helpers were used to facilitate reconciliatory intentions. Cehajic-Clancy \& Bilewicz (2017) [21] designed an intervention-present intergroup contact combined with acknowledgement of past outgroup moral exemplars-that enabled participants to deconstruct group boundaries (more heterogeneous perception of outgroup members' role in the con- 
flict) and to perceive the others as being closer (decreased intergroup anxiety, increased belief in humanity, increased contact intentions). Even if we do not know to what extent these results are due to the use of the narratives about heroic helpers and to what extent to the contact and activities with aims [79] shared by participants with different group affiliations, the intervention seems to have successfully facilitated reconciliation and strengthened interactions between groups with a conflictual past. In the study of Bilewicz \& Jaworska (2013) [20], an ingroup moral exemplar helped Polish participants, who assigned a bystander role to their group in a traumatizing past event, to feel more accepted by the victimized group, which in turn mediated perceived similarity of the outgroup and reduced psychological distance. The dependent variable was acceptance, since the needs-based model predicts that, reconciliation requires perpetrators (as well as bystanders according to the findings) to restore their moral image in order to feel more accepted by the victimized group.

In our view, however, bystanders' and perpetrators' must take responsibility for their past wrongdoings before being accepted in order to engage in the process of reconciliation, insofar as reconciliation is considered as intergroup cooperation that is also aimed at reducing the "imbalance that the harmdoing has created" [79]. If responsibility taking does not precede the satisfaction of needs to cooperate and to create shared objectives-as, for example, a shared and institutionalized historical narrative of what happened could be-advocates of the dominant positions may easily take control of these negotiation processes and promote historical revisionism, for example, which is more consistent with the dominant group's narrative.

What kind of tools can we offer for fostering reconciliation? As we learned from the above mentioned two studies, presenting past heroic actors can facilitate positive intergroup relations. Our study focused on the underlying process and its predictive relationship with present and future intergroup relations. Does it have a general effect extended to other intergroup conflicts with different outgroups?

We used the heroic helper story instead of satisfying the need for being accepted in order to encourage the acknowledgement and elaboration of past wrongdoings, which requires responsibility - taking a requisite for reparative actions. Exposure to the dissenting position represented by the heroic helper's actions sufficiently reduced perceived past ingroup homogeneity to enable group members to deal with guilt and take collective responsibility for what happened. Likewise, perception of possible choices in each situation, even when norms are perceived as strict constraints, can help us to think about available or imaginable alternatives and consequently about our own responsibility. This is why we assessed responsibility-taking, and the influence of the moral lesson from the past on current intergroup perceptions and behaviours.

The heroic helper's narrative in our study increased ingroup responsibility for the Holocaust, the use of personal pronouns in the explanations of individual 
responsibility-taking, and general empatic competences. The dissenting position represented by the heroic helper enabled participants to question the perceived normative frame and face past misdeeds of the ingroup, which resulted in more active self-expression reflected in first person pronouns and higher general emphatical competences. However, responsibility-taking was not generalized to ongoing conflicts, nor did prejudice against minorities decrease. This lack of generalization may be due to various reasons from the current Hungarian normative frame and values to the acknowledgment of an implicit parallelism between the past genocide and currently arising conflicts.

We expected that identification with the national ingroup holds the gap between past and present values and perceptions, and that it would mediate the effects of the heroic helper narrative. Glorification and attachment did not prove mediators of these effects. In the experimental condition, however, glorification showed higher covariation with intergroup variables such as acceptance of responsibility for past wrongdoings and for current conflicts, and with most social distance scales, while it did not show a negative relationship with individual responsibility as observed in the control condition. The heroic helper story contextualized the readers, activated participants' national identity, who expressed themselves accordingly. That is, stories may function as activators of identity, which provides a context that orients readers' thinking and behaviour.

An important limitation of the study is that participants' present values were not assessed (evaluation of Ocskay as a hero), which would allow for a better understanding of the observed lack of generalization. Furthermore, long-term effects of the stimulus narrative should be assessed as well.

Stories of heroic helpers of the past are interpreted in a network of possible identifications existing in the normative frame of the present. In general, the quality and extent of the impact of a moral narrative on its readers presumably depends on readers' current value systems and identity states. Knowledge of a past ingroup helper acting against dominant ingroup norms may have different effects depending on the relationship between the present and past value system and on the present forms of national identification. A hero of the past may be considered a hero in the present if her/his moral actions are positively valued in the present dominant social frame. Moreover, the past ingroup moral frame may be discussed and questioned if the present ingroup frame allows different forms and processes of identifications and supports alternative identifications rather than demanding blind conformity to the ingroup. The subjective experience of threat in intergroup relations restricts this possibility of self-questioning.

However, there is an effect of stories about ingroup helpers acting against ingroup crimes, whose extent varies with changes in the present frame. When intergroup hostility arises and there is a general perception of ingroup threat, the impact of such stories is confined within a strict normative frame and may not be generalized to other intergroup relations. In more peaceful social contexts, however, these stories may help group members discuss and question moral choices as well as individual and collective responsibilities. 


\section{Conclusions}

In our study we find out that present type of identifications defines how we deal with the collective past as well as with present intergroup conflicts. Alternative narratives as heroic helpers stories acting against past group norms can help to increase collective responsibility for the wrongdoings of the group, probably because they render the group perception more heterogeneous and evoke individuals' own responsibility. Heroic helpers stories can also increase general empathic abilities. However the responsibility is not necessarily generalizable to nowadays conflicts; the empathic abilities with others are less mobilized when ingroup identification is activated.

In line with these results we suggest that using heroic helpers narratives in reconciliatory activities, in history teaching, in informal trainings etc, can be useful to increase empathic abilities, or for the reduction of prejudice and present intergroup conflicts; however other activities could follow to strengthen the extention of its effect. Expanding possible identifications and activating different group memberships, exploring the concepts of norms, conformity and values, and helping the abstraction and acknowledgment of perpetrator-victimhood dynamics and circularity can be among these activities.

\section{Acknowledgements}

This study was funded by the National Research, Development and Innovation Office-NKFIH [K 119793 The influence of social identity on intergroup prejudice and collective action].

The first author was granted with János Bólyai Research Scholarship of the Hungarian Academy Sciences.

\section{Conflicts of Interest}

The authors declare no conflicts of interest regarding the publication of this paper.

\section{References}

[1] Liu, J.H. and Hilton, D.J. (2005) How the Past Weighs on the Present: Social Representations of History and Their Role in Identity Politics. British Journal of Social Psychology, 44, 537-556. https://doi.org/10.1348/014466605X27162

[2] Liu, J.H. and László, J. (2007) A Narrative Theory of History and Identity: Social Identity, Social Representations, Society and the Individual. In: Moloney, G. and Walker, I., Eds., Social Representations and History, Palgrave-Macmillan, New York, 85-107. https://doi.org/10.1057/9780230609181_6

[3] Lois, J. (2003) Heroic Efforts: The Emotional Culture of Search and Rescue Volunteers. New York University Press, New York.

[4] Flanagan, O. (1993) Varieties of Moral Personality: Ethics and Psychological Realism. Harvard University Press, Cambridge.

[5] Franco, Z. and Zimbardo, P. (2006) The Banality of Heroism. The Greater Good, 2006-07(1), 30-35. 
https://www.researchgate.net/publication/292266731_The_banality_of_heroism

[6] Halbwachs, M. (1950) On Collective Memory. The Heritage of Sociology. The University of Chicago Press, Chicago \& London.

[7] Shnabel, N. and Nadler, A. (2008) A Needs-Based Model of Reconciliation: Satisfying the Differential Emotional Needs of Victim and Perpetrator as a Key to Promoting Reconciliation. Journal of Personality and Social Psychology, 94, 116-132. https://doi.org/10.1037/0022-3514.94.1.116

[8] Shnabel, N., Nadler, A., Canetti-Nisim, D. and Ullrich, J. (2008) The Role of Acceptance and Empowerment from the Perspective of the Needs-Based Model. Social Issues and Policy Review, 2, 159-186. https://doi.org/10.1111/j.1751-2409.2008.00014.x

[9] Nadler, A. (2002) Post-Resolution Processes: Instrumental and Socioemotional Routes to Reconciliation. In: Salomon, G. and Nevo, B., Eds., Peace Education: The Concept, Principles, and Practices around the World, Erlbaum, Mahwah, 127-141.

[10] Nadler, A. and Liviatan, I. (2004) Intergroup Reconciliation Process in Israel: Theoretical Analysis and Empirical Findings. In: Branscombe, N.R. and Doosje, B., Eds., Collective Guilt. International Perspectives, Cambridge University Press, New York, 216-235. https://doi.org/10.1525/aa.2006.108.2.406

[11] Nadler, A. and Liviatan, I. (2006) Intergroup Reconciliation: Effects of Adversary's Expressions of Empathy, Responsibility, and Recipients' Trust. Personality \& Social Psychology Bulletin, 32, 459-470. https://doi.org/10.1177/0146167205276431

[12] Blatz, C.W., Schumann, K. and Ross, M. (2009) Government Apologies for Historical Injustices. Political Psychology, 30, 219-241.

https://doi.org/10.1111/j.1467-9221.2008.00689.x

[13] Bar-Tal, D. and Bennik, G.H. (2004) The Nature of Reconciliation as an Outcome and as a Process. In: From Conflict Resolution to Reconciliation, Oxford University Press, Oxford, 11-83. https://doi.org/10.1093/acprof:oso/9780195166439.003.0002

[14] Bilali, R. and Vollhardt, J.R. (2013) Priming Effects of a Reconciliation Radio Drama on Historical Perspective-Taking in the Aftermath of Mass Violence in Rwanda. Journal of Experimental Social Psychology, 49, 144-151. https://doi.org/10.1016/j.jesp.2012.08.011

[15] Staub, E. (2011) Overcoming Evil: Genocide, Violent Conflict, and Terrorism. Oxford University Press, Oxford. https://doi.org/10.1093/acprof:oso/9780195382044.001.0001

[16] Bar-Tal, D. (2000b) From Intractable Conflict through Conflict Resolution to Reconciliation: Psychological Analysis. Political Psychology, 21, 351-365. https://doi.org/10.1111/0162-895X.00192

[17] László, J. (2008) Narratív pszichológia. Pszichológia, 28, 301-317. https://doi.org/10.1556/Pszicho.28.2008.4.1

[18] Bar-Tal, D. (2013) Intractable Conflicts: Socio-Psychological Foundations and Dynamics. Cambridge University Press, New York. https://doi.org/10.1017/CBO9781139025195

[19] Bar-Tal, D. (2018) What Palestinians Actually Know about the Holocaust. Haaretz. https://www.haaretz.com/middle-east-news/palestinians/.premium-what-palestinia ns-actually-know-about-the-holocaust-1.6075799

[20] Bilewicz, M. and Jaworska, M. (2013) Reconciliation through the Righteous: The Narratives of Heroic Helpers as a Fulfillment of Emotional Needs in Polish-Jewish Intergroup Contact. Journal of Social Issues, 69, 162-179. 
https://doi.org/10.1111/josi.12009

[21] Čehajić-Clancy, S. and Bilewicz, M. (2017) Fostering Reconciliation through Historical Moral Exemplars in a Post Conflict Society. Peace and Conflict. Journal of Peace Psychology, 23, 288-296. https://doi.org/10.1037/pac0000210

[22] Hanke, K., Liu, J.H., Hilton, D., Garber, I., Huang, L.L., Conaco, C. and Wang, F. (2013) When the Past Haunts the Present: Intergroup Forgiveness and Historical Closure in Post World War II Societies in Asia and in Europe. International Journal of Intercultural Relations, 37, 287-301. https://doi.org/10.1016/j.ijintrel.2012.05.003 https://pdfs.semanticscholar.org/beaf/6ea6f5f0c44e4678d8b9b5e2ec7f76b126cd.pdf

[23] Noor, M., Brown, J.R. and Prentice, G. (2008) Prospects for Intergroup Reconciliation: Social-Psychological Predictors of Intergroup Forgiveness and Reparation in Northern Ireland and Chile. In: Nadler, A., Malloy, T. and Fisher, J.D., Eds., Social Psychology of Intergroup Reconciliation: From Violent Conflict to Peaceful Co-Existence-Going beyond Victimization, Guilt and Distrust, Oxford University Press, Oxford, 97-114. https://doi.org/10.1093/acprof:oso/9780195300314.003.0006

[24] Vollhardt, J.R. and Bilewicz, M. (2013) After the Genocide: Psychological Perspectives on Victim, Bystander, and Perpetrator Groups. Journal of Social Issues, 69, 1-15. https://doi.org/10.1111/josi.12000

[25] Čehajić, S., Brown, R. and Catano, E. (2008) Forgive and Forget? Antecedents and Consequences of Intergroup Forgiveness in Bosnia and Herzegovina. Political Psychology, 29, 351-367. https://doi.org/10.1111/j.1467-9221.2008.00634.x

[26] Hewstone, M., Cairns, E., Voci, A., Hamberger, J. and Niens, U. (2006) Intergroup Contact, Forgiveness, and Experience of "The Troubles" in Northern Ireland. Journal of Social Issues, 62, 99-120. https://doi.org/10.1111/j.1540-4560.2006.00441.x

[27] Oliner, S.P. and Oliner, P.M. (1988) The Altruistic Personality: Rescuers of Jews in Nazi Europe. Free Press, New York. https://doi.org/10.1086/603750

[28] Smolenska, Z. and Reykowski, J. (1992) Motivations of People Who Helped Jews Survive the Nazi Occupation. In: Oliner, P.M., Smolenska, M.Z., Oliner, S.P. and Baron, L., Eds., Embracing the Other. Philosophical, Psychological, and Historical Perspectives on Altruism, New York University Press, New York, 213-225. https://doi.org/10.2307/j.ctt9qg24m.17

[29] Staub, E. (1993) The Psychology of Bystanders, Perpetrators, and Heroic Helpers. International Journal of Intercultural Relations, 17, 315-341. https://doi.org/10.1016/0147-1767(93)90037-9

[30] Roccas, S., Klar, Y. and Liviatan, I. (2006) The Paradox of Group-Based Guilt: Modes of National Identification, Conflict Vehemence, and Reactions to the Ingroup's Moral Violations. Journal of Personality and Social Psychology, 91, 698-711. https://doi.org/10.1037/0022-3514.91.4.698

[31] Staub, E. (2003) The Psychology of Good and Evil: Children, Adults and Groups Helping and Harming Others. Cambridge University Press, New York. https://doi.org/10.1017/CBO9780511615795

[32] Peetz, J., Gunn, G.R. and Wilson, A.E. (2010) Crimes of the Past: Defensive Temporal Distancing in the Face of Past In-Group Wrongdoing. Personality and Social Psychology Bulletin, 36, 598-611. https://doi.org/10.1177/0146167210364850

[33] Bocchiaro, P. and Zimbardo, P. (2017) On the Dynamics of Disobedience: Experimental Investigations of Defying Unjust Authority. Psychology Research and Behavior Management, 10, 219-229. https://doi.org/10.2147/PRBM.S135094

[34] Janis, I.L. (1972) Victims of Groupthink: A Psychological Study of Foreign-Policy Decisions and Fiascoes. Houghton Mifflin, Oxford. 
[35] Reicher, S., Haslam, S.A. and Rakshi, R. (2008) Making a Virtue of Evil: A Five-Step Social Identity Model of the Development of Collective Hate. Social and Personality Psychology Compass, 2, 1313-1344. https://doi.org/10.1111/j.1751-9004.2008.00113.x

[36] Milgram, S. (1974) Obedience to Authority: An Experimental View. Tavistock Publications, London.

[37] Sunstein, C.R. (2002) Conformity and Dissent. Public Law Research Paper 34, Chicago. https://ssrn.com/abstract $=341880$ https://doi.org/10.2139/ssrn.341880

[38] Tajfel, H. (1981) Human Groups and Social Categories: Studies in Social Psychology. European Journal of Social Psychology, 12, 213-219.

https://doi.org/10.1002/ejsp.2420120209

[39] Doise, W. (1988) Individual and Social Identities in Intergroup Relations. European Journal of Social Psychology, 18, 99-111. https://doi.org/10.1002/ejsp.2420180202

[40] Ellemers, N., Spears, R. and Doosje, B. (1999) Social Identity: Context, Commitment, Content. Blackwell Publishers, Oxford.

[41] Ferguson, T.J. and Stegge, H. (1998) Measuring Guilt in Children: A Rose by Any Other Name Still Has Thorns. In: Bybee, J., Ed., Guilt and Children, Academic Press, San Diego, 19-74. https://doi.org/10.1016/B978-012148610-5/50003-5

[42] Frijda, N.H., Kuipers, P. and ter Schure, E. (1989) Relations among Emotion, Appraisal, and Emotional Action Readiness. Journal of Personality and Social Psychology, 57, 212-228. https://doi.org/10.1037/0022-3514.57.2.212

[43] Wohl, M.J.A., Branscombe, N.R. and Klar, Y. (2006) Collective Guilt: Emotional Reactions When One's Group Has Done Wrong or Been Wronged. European Review of Social Psychology, 17, 1-37. https://doi.org/10.1080/10463280600574815

[44] Bandura, A. (1999) Moral Disengagement in the Perpetration of Inhumanities. Personality and Social Psychology Review, 3, 193-209. https://doi.org/10.1207/s15327957pspr0303_3

[45] Feather, N.T. (2006) Values, Achievement, and Justice: Studies in the Psychology of Deservingness. Springer Science and Business Media, New York.

[46] Xu, H., Bègue, L. and Shankland, R. (2011) Guilt and Guiltlessness: An Integrative Review. Social and Personality Psychology Compass, 5, 440-457. https://doi.org/10.1111/j.1751-9004.2011.00364.x

[47] Tajfel, H. (1979) Individuals and Groups in Social Psychology. The British Journal of Social and Clinical Psychology, 18, 183-190. https://doi.org/10.1111/j.2044-8260.1979.tb00324.x

[48] Szabó, Zs. and László, J. (2014) Identification with the National Ingroup: A Hungarian Questionnaire. Hungarian Journal of Psychology, 69, 293-318. https://doi.org/10.1556/MPSzle.69.2014.2.1

[49] Szabó, Zs., Mészáros, N. and Csertő, I. (2017) The Role of Perceived In-Group Moral Superiority in Reparative Intentions and Approach Motivation. Frontiers in Psychology, 8, 912. https://doi.org/10.3389/fpsyg.2017.00912

[50] Doosje, B., Branscombe, N.R., Spears, R. and Manstead, A.S.R. (1998) Guilt by Association: When One's Group Has a Negative History. Journal of Personality and Social Psychology, 75, 872-886. https://doi.org/10.1037/0022-3514.75.4.872

[51] Leach, C.W. (2017) Understanding Shame and Guilt. In: Woodyat, L., Worthington, E.L., Wenzel, M. and Griffin, B.J., Eds., Handbook of the Psychology of Self-Forgiveness, Springer International Publishing, Cham, 17-28. 
https://doi.org/10.1007/978-3-319-60573-9_2

[52] Schatz, R.T., Staub, E. and Lavine, H. (1999) On the Varieties of National Attachment: Blind versus Constructive Patriotism. Political Psychology, 20, 151-174.

https://doi.org/10.1111/0162-895X.00140

[53] Roccas, S., Sagiv, L., Schwartz, S., Halevy, N. and Eidelson, R. (2008) Toward a Unifying Model of Identification with Groups: Integrating Theoretical Perspectives. Personality and Social Psychology Review, 12, 280-306. https://doi.org/10.1177/1088868308319225

[54] Hunyady, Gy. (2014) Visszatekintés a jelenböl. In: Hunyady, Gy. and Török, L., Eds., Történelem és emlékezet: Egy akadémiai ülésszak előadása, Kossuth Kiadó, Budapest, 9-26.

[55] Braham, R.L. (2016) The Politics of Genocide: The Holocaust in Hungary. Columbia University Press, New York.

[56] Ungváry, R. (2014) The Invisible Reality: Fascistoid Mutation in Today’s Hungary. Pesti Kalligram Kft, Budapest.

[57] Lázár, Gy. (2015) Writings of Albert Wass Are a Poor Choice for New York City Celebration.

http://hungarianfreepress.com/2015/02/03/writings-of-albert-wass-are-a-poor-choi ce-for-new-york-city-celebration

[58] Erőss, Á. (2016) "In Memory of Victims": Monument and Counter-Monument in Liberty Square, Budapest. Hungarian Geographical Bulletin, 65, 237-254. https://doi.org/10.15201/hungeobull.65.3.3

[59] Hirschberger, G., Kende, A. and Weinstein, S. (2016) Defensive Representations of an Uncomfortable History: The Case of Hungary and the Holocaust. International Journal of Intercultural Relations, 55, 32-43. https://doi.org/10.1016/j.ijintrel.2016.08.006

[60] Bergmann, W. (2006) History of Antisemitism. Beck, Munich.

[61] Imhoff, R. and Banse, R. (2009) Ongoing Victim Suffering Increases Prejudice: The Case of Secondary Anti-Semitism. Psychological Science, 20, 1443-1447. https://doi.org/10.1111/j.1467-9280.2009.02457.x

[62] Čehajic, S. and Brown, R. (2010) Silencing the Past: Effects of Intergroup Contact on Acknowledgment of In-Group Responsibility. Social Psychological and Personality Science, 1, 190-196. https://doi.org/10.1177/1948550609359088

[63] Allport, G.W. (1954/1979) The Nature of Prejudice. Basic Books, Cambridge/Reading.

[64] Adorno, T., Frenkel-Brunswik, E., Levinson, D. and Sanford, R. (1950/1993) The Authoritarian Personality. Norton, New York.

[65] McCrae, R.R. and Costa, P.T. (2008) The Five-Factor Theory of Personality. In: John, O.P., Robins, R.W. and Pervin, L.A., Eds., Handbook of Personality: Theory and Research, Guilford Press, New York, 159-181.

[66] McCrae, R.R. and Sutin, A.R. (2009) Openness to Experience. In: Leary, M.R. and Hoyle, R.H., Eds., Handbook of Individual Differences in Social Behavior, Guilford, New York, 257-273.

[67] Altemeyer, B. (1981) Right-Wing Authoritarianism. University of Manitoba Press, Winnipeg.

[68] Sidanius, J. and Pratto, F. (1999) Social Dominance: An Intergroup Theory of Social Hierarchy and Oppression. Cambridge University Press, New York. https://doi.org/10.1017/CBO9781139175043 
[69] Kende, A., Hadarics, M. and Lášticová, B. (2017) Anti-Roma Attitudes as Expressions of Dominant Social Norms in Eastern Europe. International Journal of Inte rcultural Relations, 60, 12-27. https://doi.org/10.1016/j.ijintrel.2017.06.002

[70] Bigazzi, S., Siegler, A., Serdült, S., Bokrétás, I. and Takács, B. (2019) A Measure of Perceived Identity Threat and of Distancing Relevant Others: Development of the Multiple Threat and Prejudice Questionnaire. Open Journal of Social Sciences.

[71] Matache, M. (2014) Accelerating Patterns of Anti-Roma Violence in Hungary. FXB Center for Health and Human Rights, Harvard School of Public Health, Boston. https://cdn2.sph.harvard.edu/wp-content/uploads/sites/114/2017/12/FXB-HungaryReport_Released-February-3-2014.pdf

[72] Orosz, G., Bruneau, E., Tropp, L.R., Sebestyén, N., Tóth-Király, I. and Bőthe, B. (2018) What Predicts Anti-Roma Prejudice? Qualitative and Quantitative Analysis of Everyday Sentiments about the Roma. Journal of Applied Social Psychology, 48, 317-328. https://doi.org/10.1111/jasp.12513

[73] Bar-Tal, D., Chernyak-Hai, L., Schori, N. and Gundar, A. (2009) A Sense of Self Perceived Collective Victimhood in Intractable Conflicts. International Review of the Red Cross, 91, 229-258. https://doi.org/10.1017/S1816383109990221

[74] Leach, C.W., Iyer, A. and Pedersen, A. (2006) Anger and Guilt about Ingroup Advantage Explain the Willingness for Political Action. Personality and Social Psychology Bulletin, 32, 1232-1245. https://doi.org/10.1177/0146167206289729

[75] Nyáry, K. (2014) Igazi hősök [Real Heroes]. Corvina Kiadó, Budapest.

[76] Davis, M.H. (1983) Measuring Individual Differences in Empathy: Evidence for a Multidimensional Approach. Journal of Personality and Social Psychology, 44, 113-126. https://doi.org/10.1037/0022-3514.44.1.113

[77] Bogardus, E.S. (1925) Measuring Social Distances. Journal of Applied Sociology, 9 , 299-308. https://brocku.ca/MeadProject/Bogardus/Bogardus_1925c.html

[78] Hayes, A.F. (2012) Process: A Versatile Computational Tool for Observed Variable Mediation, Moderation, and Conditional Process Modeling [White Paper]. http://www.afhayes.com/public/process2012.pdf

[79] Straub, J. (2005) Telling Stories, Making History. In: Straub, J., Ed., Narration, Identity, and Historical Consciousness, Berghan Books, New York, 44-98. 